\title{
Diagnostic value of initial s-100b and neuron- specific enolase levels in diabetic patients with ischemic stroke
}

\author{
***Nagwa K. Roshdy*, Abir Zakaria**, Hala Kahla**, Suzan Samy \\ Medical Biochemistry, **Internal Medicine and *Departments of \\ $* * *$ Radiodiagnosis, Faculty of Medicine, Cairo University
}

\begin{abstract}
Diabetics have a high risk of ischemic stroke. The present study aimed at evaluating the diagnostic validity of immediate measurements of serum S-100B and NeuronSpecific Enolase (NSE) in comparison with neurological examinations and cerebral computed tomography (CT) findings in diabetic ischemic stroke patients. It also aimed at determining the possible influence of type 2 diabetes mellitus, either or not complicated with stroke, on serum levels of S-100B and NSE. Another objective of the current study was the determination of serum malondialdehyde (MDA) as an indicator of lipid peroxidation (LPO) to detect any possible correlation between LPO and S-100B or NSE.

This cross sectional study included 66 subjects; 46 diabetic patients and 20 healthy subjects. Participants were classified into the following groups: Group I: 25 diabetic patients (type 2) with acute stroke. Group II: 21 uncomplicated controlled type 2 diabetic patients. Group III: 20 apparently healthy age and sex matched control subjects. Serum levels of S-100B and NSE were assessed by ELIZA technique. MDA levels were measured using a chemical method. Results of this work showed that the mean levels of serum S-100B and NSE in diabetic patients with cerebrovascular stroke were significantly higher than the corresponding mean values in uncomplicated diabetic patients and in control subjects $(P<0.001)$. Serum $S-100 B$ levels in diabetic stroke patients showed significant positive correlation with the infarct size as assessed by the CT brain $(r=0.9816, P<0.001)$. Similarly, serum levels of NSE correlated positively with infarct size $(r=0.9384, P<0.001)$. No significant correlation was observed between levels of S-100B and NSE on one hand and glycemic control and duration of diabetes on the other. Also, MDA showed statistically significant elevation in diabetics with stroke compared to its corresponding values in uncomplicated diabetics and control groups $(P<0.001)$.

In conclusion: Serum levels of S-100B and NSE correlated with the neurological clinical findings, as well as the infarct size as assessed by brain CT. So, S-100B and NSE measurements immediately after admission might help to reduce serial CT scans of the brain of ischemic stroke in diabetic patients. Future studies are recommended to follow the S-100B and NSE serum levels after thrombolytic therapy. Elevation of MDA in diabetic patients, which was significantly higher in diabetic patients complicated with stroke compared to uncomplicated diabetics, might direct the attention to further studies on the role of antioxidants in such patients.
\end{abstract}

\section{INTRODUCTION}

Diabetics have at least twice the risk of stroke and may show performance deficit in a wide range of cognitive domains ${ }^{(\mathbf{1})}$. The mechanisms underlying this end-organ damage may involve both vascular changes through promotion of a prothrombotic state, endothelial dysfunction ${ }^{(2)}$ and direct damage to neuronal cells as a result of overproduction of reactive 
oxygen species by the respiratory chain and consequent oxidative stress $^{(3)}$. Oxidant radicals contribute to increased neuronal death by oxidizing proteins, damaging DNA, and inducing the lipoperoxidation of cellular membranes ${ }^{(4)}$.

S-100 protein constitutes a large family of at least 20 proteins. It is an acidic calcium-binding protein with a molecular weight of $21 \mathrm{kDa}$ consisting of two subunits alpha and beta $^{(5)}$. It is found as homo- or heterodimers of two different subunits (A and B). Types S 100-AB and S 100$\mathrm{BB}$ are described as $\mathrm{S}-100 \mathrm{~B}$ protein and are shown to be highly specific for nervous tissue. It is present in the cytosol of glial and Schwann cells, and also in adipocytes and chondrocytes, although in very low concentrations in the latter two. The role of protein S-100B is not yet fully understood. It is suggested that it has intracellular and extracellular neurotropic as well as neurotoxic function. At nanomolar levels, S-100B stimulates neurite outgrowth and enhances survival of neurons. However, at micromolar levels it stimulates the expression of inflammatory cytokines and induces apoptosis $^{(6)}$. Recently, serum S-100B protein has been proved to be an attractive surrogate marker of primary severe brain injury ${ }^{(7)}$. The S-100B protein is released by injured astrocytes. After passage through a disintegrated blood-brain barrier (BBB) the molecule can be detected in the peripheral circulation ${ }^{(\mathbf{8})}$.

Several studies have investigated the potential role of $\mathrm{S}-100 \mathrm{~B}$ as a peripheral biochemical marker of neural injury, including reactive gliosis, astrocytic death, and/or bloodbrain barrier dysfunction ${ }^{(9)}$. Increased cerebrospinal fluid (CSF) and/or serum S-100B has been reported in several acute and chronic injuries, including traumatic brain injury ${ }^{(\mathbf{1 0})}$, after single tonic-clonic seizures ${ }^{(\mathbf{1 1})}$, stroke $^{(12)}$, Alzheimer disease ${ }^{(13)}$, schizophrenia $^{(14)}$, myelopathy ${ }^{(15)}$, and systemic lupus erythematosus ${ }^{(16)}$.

NSE is a glycolytic enzyme that converts 2-phospho-D glycerate to phosphoenolpyruvate ${ }^{(\mathbf{1 7})}$. It is a soluble cytoplasmic protein localized principally in neurons. NSE was also reported to be present in platelets and red blood cells ${ }^{(\mathbf{1 8 , 1 9 )}}$. The presence of NSE in red blood cells is clinically relevant because even a mild hemolysis of $2 \%$ may increase serum NSE levels five-fold ${ }^{(20)}$.Several studies have shown that estimation of NSE in CSF yields a reliable estimate of the severity of neuronal injury as well as clinical outcome of patients with serious clinical manifestations such as in cases of stroke ${ }^{(21)}$, head injury $^{(22)}$, anoxic encephalopathy ${ }^{(23)}$, encephalitis $^{(24)}$, brain metastasis ${ }^{(25)}$, and status epilepticus ${ }^{(26)}$.

So, S-100B and NSE, distributed mainly in the central nervous system, can provide qualitative information about the extent of brain injury and are sensitive markers of brain damage after stroke and cerebral hypoxia ${ }^{(27)}$.

The present study aimed at evaluating the diagnostic validity of immediate measurements of serum S$100 \mathrm{~B}$ and NSE in comparison with cerebral computed tomography (CT) findings in diabetic ischemic stroke patients. We also aimed at determining the possible influence of type 2 diabetes mellitus, either or not 
complicated with stroke, on serum levels of S-100B and NSE. Another objective of the current study was the determination of serum malondialdehyde (MDA), as an indicator of lipid peroxidation (LPO), to detect any possible correlation between LPO and S-100B or NSE.

\section{SUBJECTS \& METHODS}

\section{Participants:}

This cross sectional study included 66 subjects; 46 diabetic patients and 20 healthy subjects. Participants were classified into the following groups:

Group I: 25 type 2 diabetic patients (13 males, 12 females) aged $53.56 \pm 2.8$ years with acute stroke symptoms consistent with cerebral ischemia in the anterior territory of vascular supply, who were admitted to Kasr El Aini internal medicine emergency unit.

Group II: 21 uncomplicated controlled type 2 diabetic patients (11 males, 10 females) aged $51.8 \pm 3$.1years. HbA1c $<7 \%$, no diabetic retinopathy detected on fundus examination. No orthostatic hypotension on measuring supine \& erect blood pressures, normal vibration sense in lower limbs. However subjectively, no history of ischemic heart disease and no ECG changes suggestive of ischemia were found.

Group III: 20 apparently healthy age and sex matched control subjects (10 males, 10 females) aged 51.15 \pm 1.59 years selected from the hospital working personnel, who had no history of significant medical problems and were not taking any medications.
Exclusion criteria: (1) diabetics reporting hypoglycemic attacks within the past year. (2) previous severe head trauma requiring at least Emergency Room (ER) management. (3) previous cerebrovascular stroke.

An informed consent was taken from all participants. The study was performed during the period from March 2006 to August 2006. Diagnosis of type 2 diabetes mellitus was made according to the American Diabetes Association (ADA) standards of medical care in Diabetes $^{(\mathbf{2 8 )}}$. They considered subjects to be diabetic if fasting plasma glucose $(\mathrm{FPG}) \geq 126 \mathrm{mg} / \mathrm{dL}$ and/or if they take treatment of diabetes. In the same guidelines ADA considered those with FPG $100-125 \mathrm{mg} / \mathrm{dL}$ to have impaired fasting glucose, and those with 2 hours postprandial blood glucose $140-199 \mathrm{mg} / \mathrm{dL}$ to have impaired glucose tolerance ${ }^{(\mathbf{1 8})}$. All the diabetic patients with and without stroke were on bed time intermediate acting insulin, and daytime oral hypoglycemic drugs (Sulphonylurea + metformin), at the time of sampling for S-100B and NSE. The diabetic stroke patients' clinical status was evaluated by clinical examination according to Glasgow coma scale ${ }^{(29)}$. Patients with cerebral hemorrhage were excluded.

\section{Sample Collection:}

Apart from the stroke group, after overnight fast, venous blood was collected into three tubes:

1. One tube containing fluoride for estimation of plasma glucose ${ }^{(30)}$. Plasma was separated by centrifugation at $3000 \mathrm{rpm}$ for 15 minutes. 
2. The second tube containing EDTA for separation of plasma and estimation of glycosylated hemoglobin (HbAlc) by the kit provided by Stanbio, Italy ${ }^{(31)}$. Insulin was estimated in plasma ${ }^{(32)}$. Insulin resistance was estimated using the homeostatic model assessment for insulin resistance (HOMA-IR) index [i.e. plasma glucose level (mmol/L) x plasma insulin $(\mu \mathrm{IU} / \mathrm{mL}) / 22.5]^{(33)}$.

3 . The third was plain tube for separation of serum. Sera were aliquot and stored at $-80^{\circ} \mathrm{C}$ until analysis.

As regards the stroke group, blood samples were withdrawn on admission to the Internal Medicine Emergency Unit, before CT brain imaging.

Determination of serum S-100B and NSE:

Serum S-100B and NSE were assessed using: the Can Ag S-100B and NSE EIA kits (CanAg Diagnostics AB Gothenburg, Sweden.) intended for the quantitative determination of S-100B ${ }^{(34)}$ and NSE (35) in human serum respectively.

\section{Determination of serum malondialdehyde (MDA):}

This method depends on acid catalysed thermal deposition of lipid peroxide to MDA which reacts with thiobarbituric acid (TBA) to form a colored product, which can be estimated colorimetrically ${ }^{(36)}$.

Computerized Tomography (CT) for evaluation of brain lesions' topography and size:
Evaluation of lesion topography and size of infarcted brain area was based on cranial CT data, after sampling for the tested biomarkers for all diabetic ischemic stroke patients. All patients were examined using general electric multislice 4 detectors at Radiology Department of Kasr El Aini University Hospital. Patients with initially negative CT brain, for cerebral infarcts, were subjected to a follow up CT brain imaging 72 hours later.

\section{Imaging technique:}

- The patients' head was supine slightly extended and the plane of section at $10-22^{\circ}$ to orbitomeatal line.

- Axial plane

- Slice thickness $10 \mathrm{~mm}$ in the brain, $3.75 \mathrm{~mm}$ in the posterior fossa

- Noncontrast CT.

- Soft tissue window.

- Size of infarct was estimated.

- A cutoff level of $5 \mathrm{~cm}^{3}$ was used to categorize the patients.

\section{Statistical analysis:}

All analyses were performed using the Statistical Package for Social Sciences (SPSS) software. Numerical data were expressed as mean \pm SD. Comparisons were performed by analysis of variance "ANOVA" on ranks, Scheffe's test was used as a post-hoc test. Correlations were tested by spearman's test. Comparisons and correlations were considered statistically significant when $\mathrm{P}<$ $0.05^{(37)}$. 


\section{RESULTS}

Table (1): Demographic data, PG, PI, HOMA and Hb A1c in the studied groups.

\begin{tabular}{|c|c|c|c|}
\hline & $\begin{array}{c}\text { Diabetics with } \\
\text { Stroke } \\
\mathbf{N}=\mathbf{2 5}\end{array}$ & $\begin{array}{c}\text { Uncomplicated } \\
\text { DM } \\
\mathbf{N}=21\end{array}$ & $\begin{array}{l}\text { Control } \\
\mathbf{N}=\mathbf{2 0}\end{array}$ \\
\hline $\begin{array}{l}\text { Age (Years) } \\
\text { P1 } \\
\text { P2 }\end{array}$ & $\begin{array}{l}53.56 \pm 2.8 \\
\text { NS }\end{array}$ & $\begin{array}{l}51.8 \pm 3.1 \\
\mathrm{NS} \\
\mathrm{NS}\end{array}$ & $\begin{array}{l}51.15 \pm 1.59 \\
\mathrm{NS}\end{array}$ \\
\hline $\mathrm{M} / \mathrm{F}$ & $13 / 12$ & $11 / 10$ & $10 / 10$ \\
\hline $\begin{array}{l}\text { Duration of diabetes (Years) } \\
\text { P2 }\end{array}$ & $8.4 \pm 4.2$ & $\begin{array}{l}3.52 \pm 1.6 \\
<0.001\end{array}$ & \\
\hline $\begin{array}{l}\mathrm{BMI}\left(\mathrm{Kg} / \mathrm{m}^{2}\right) \\
\mathrm{P} 1 \\
\mathrm{P} 2\end{array}$ & $\begin{array}{l}25.5 \\
\mathrm{NS}\end{array}$ & $\begin{array}{l}26.01 \\
\mathrm{NS} \\
\mathrm{NS}\end{array}$ & $\begin{array}{l}25.1 \\
\mathrm{NS}\end{array}$ \\
\hline $\begin{array}{l}\text { PG }(\mathrm{mg} / \mathrm{dL}) \\
\text { P1 }\end{array}$ & $8.2 \pm 1.75^{*}$ & $\begin{array}{l}6.8 \pm 0.7 \\
<0.001\end{array}$ & $4.94 \pm 0.5$ \\
\hline $\begin{array}{l}\mathrm{PI}(\mu \mathrm{IU} / \mathrm{mL}) \\
\mathrm{P} 1\end{array}$ & $38.48 \pm 5.66^{*}$ & $\begin{array}{l}33.47 \pm 5.54 \\
<0.001\end{array}$ & $13.31 \pm 1.48$ \\
\hline $\begin{array}{l}\text { HOMA } \\
\text { P1 }\end{array}$ & $*$ & $\begin{array}{l}10.1 \pm 2.75 \\
<0.001\end{array}$ & $2.92 \pm 0.74$ \\
\hline $\begin{array}{l}\mathrm{Hb} \text { Alc }(\%) \\
\text { P1 } \\
\text { P2 }\end{array}$ & $\begin{array}{l}7.3 \pm 0.6 \\
<0.001\end{array}$ & $\begin{array}{l}6.2 \pm 0.5 \\
<0.01 \\
>0.05\end{array}$ & $\begin{array}{l}4.37 \pm 0.34 \\
<0.001\end{array}$ \\
\hline
\end{tabular}

*Samples for plasma glucose and insulin in "Stroke group" were taken on admission (random). They were not compared with other groups (fasting).

Levels are expressed as means $\pm S D$.

BMI: body mass index; PG: plasma glucose; PI; plasma insulin; HOMA-IR: homeostasis model assessment for insulin resistance; HbA1c: glycated hemoglobin A1c.

P1 comparison between each group and control, P2 comparison between each group and stroke, NS : non significant.

Table 1 shows demographic data, plasma glucose (PG), plasma insulin (PI), insulin resistance (HOMA-IR) and HbAlc in the studied groups. All groups were age and sex matched. Also, there was no statistically significant difference among the groups as regards BMI. Stroke patients had significantly longer duration of diabetes than the controlled diabetics $(\mathrm{P}<0.001)$. PG, PI, HOMA-IR and $\mathrm{Hb} \mathrm{A} 1 \mathrm{c}$ were significantly higher in diabetic patients compared to the controls. $(\mathrm{P}<0.001, \mathrm{P}<0.001$, $\mathrm{P}<0.001$ and $\mathrm{P}<0.01$ respectively).HbA1c was still higher in the stroke group compared to the controls $(\mathrm{P}<0.001)$. There was no statistically significant difference between the stroke and controlled diabetic groups as regards HbAlc $(\mathrm{P}>0.05)$. However, Samples for plasma glucose and insulin in "Stroke group" were taken on admission (random). They were not compared with other groups (fasting). 
Table (2) Levels of MDA, S 100 - B and NSE in the studied groups.

\begin{tabular}{|c|c|c|c|}
\hline & $\begin{array}{c}\text { Diabetics with } \\
\text { Stroke } \\
\mathrm{N}=25\end{array}$ & $\begin{array}{c}\text { Uncomplicated } \\
\text { DM } \\
\mathrm{N}=21\end{array}$ & $\begin{array}{l}\text { Control } \\
\mathbf{N}=\mathbf{2 0}\end{array}$ \\
\hline $\begin{array}{l}\text { MDA (nmol/L) } \\
\text { P1 } \\
\text { P2 }\end{array}$ & $\begin{array}{l}19.52 \pm 1.78 \\
<0.001\end{array}$ & $\begin{array}{l}11.05 \pm 0.5 \\
<0.001 \\
<0.001\end{array}$ & $\begin{array}{l}3.39 \pm 0.5 \\
<0.001\end{array}$ \\
\hline $\begin{array}{ll}(\mu g / L) & S-100 B \\
\text { P1 } & \\
\text { P2 } & \end{array}$ & $\begin{array}{l}115.18 \pm 7.45 \\
<0.001\end{array}$ & $\begin{array}{l}9.58 \pm 2.06 \\
<0.001 \\
<0.001\end{array}$ & $\begin{array}{l}28.22 \pm 7.9 \\
<0.001\end{array}$ \\
\hline $\begin{array}{l}\text { NSE }(\mu \mathrm{g} / \mathrm{L}) \\
\mathrm{P} 1 \\
\mathrm{P} 2\end{array}$ & $\begin{array}{l}14.42 \pm 4.09 \\
<0.001\end{array}$ & $\begin{array}{l}7.34 \pm 1.68 \\
>0.05 \\
<0.001\end{array}$ & $\begin{array}{l}6.71 \pm 1.29 \\
<0.001\end{array}$ \\
\hline
\end{tabular}

Values are means $\pm S D$.

MDA; malondialdehyde; NSE; neuron specific enolase.

P1 comparison between each group and control, P2 comparison between each group and stroke.

Table (2) shows the levels of MDA, S-100 B and NSE in the studied groups. MDA was significantly higher in the stroke group compared to each of the controls and controlled diabetics $(\mathrm{P}<0.001) . \mathrm{S}-100 \mathrm{~B}$ and NSE were significantly higher in the stroke group compared to each of the controls and controlled diabetics $(\mathrm{P}<0.001)$. However, the levels of S-100B were significantly lower in the uncomplicated diabetic group compared to the control group and the stroke group $(\mathrm{P}<0.001)$. There was no statistically significant difference between levels of NSE between the controlled diabetics and the controls $(\mathrm{P}>0.05)$.

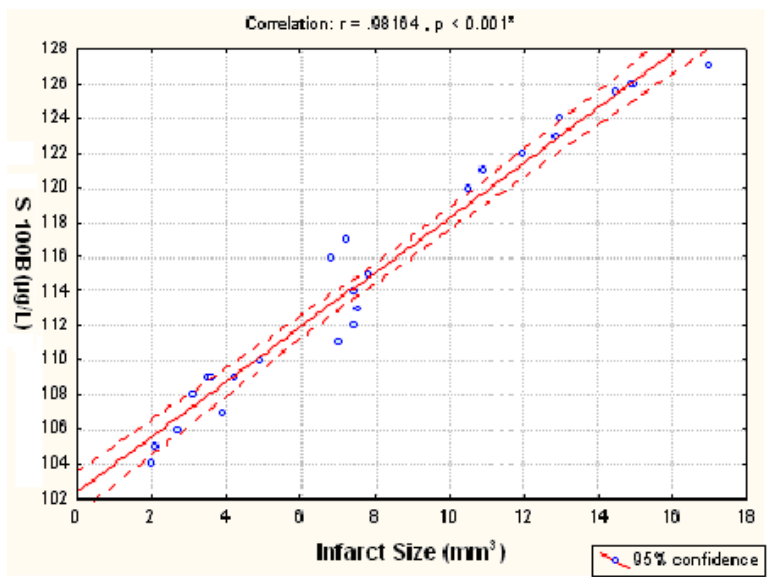

Figure (1) Correlation between $S-100 B$ and infarct size

Figure 1 shows a significantly positive correlation between levels of S-100B and the infarct size. $(r=0.98164, \mathrm{P}<0.001)$. 


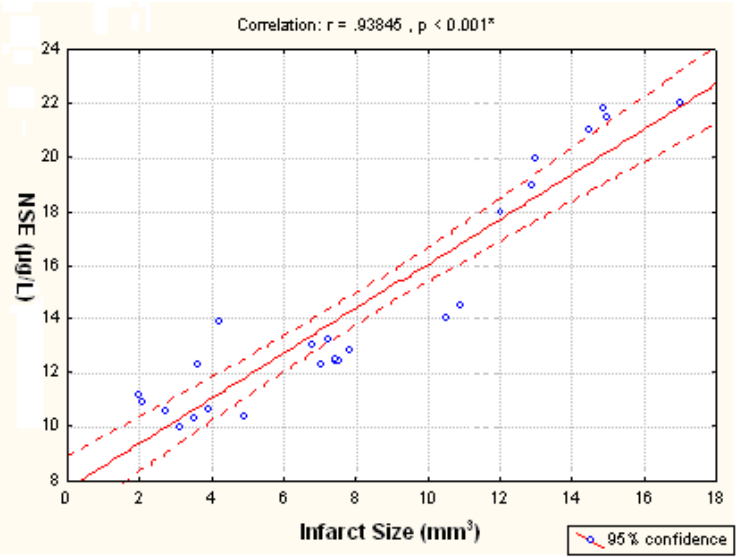

Figure (2) Correlation between levels of NSE and infarct size.

Figure 2 shows a significantly positive correlation between levels of NSE and the infarct size. $\quad(\mathrm{r}=0.93845, \quad \mathrm{P}<0.001)$

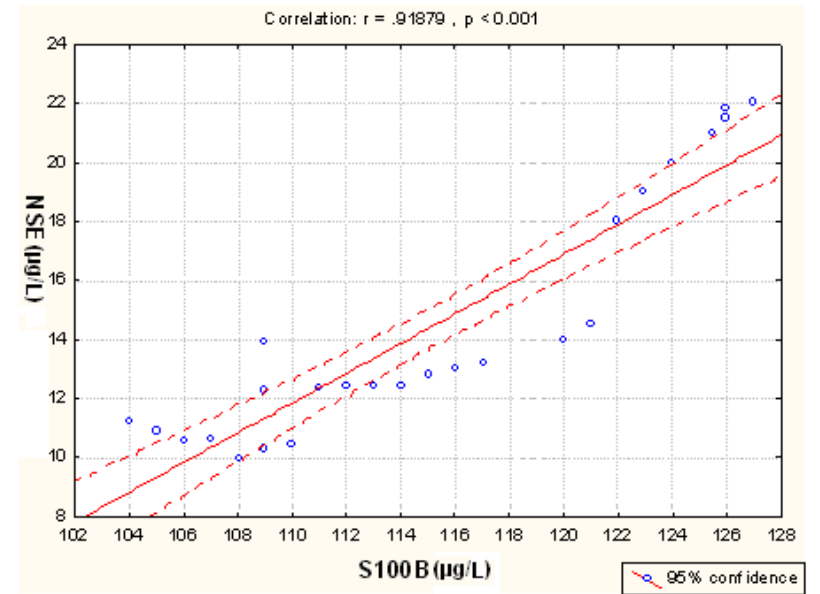

Figure (3) Correlation between levels of S-100B and NSE in the stroke group.

Figure 3 shows a significantly positive correlation between levels of S-100B and NSE $(r=0.91879, \mathrm{P}<0.001)$. 


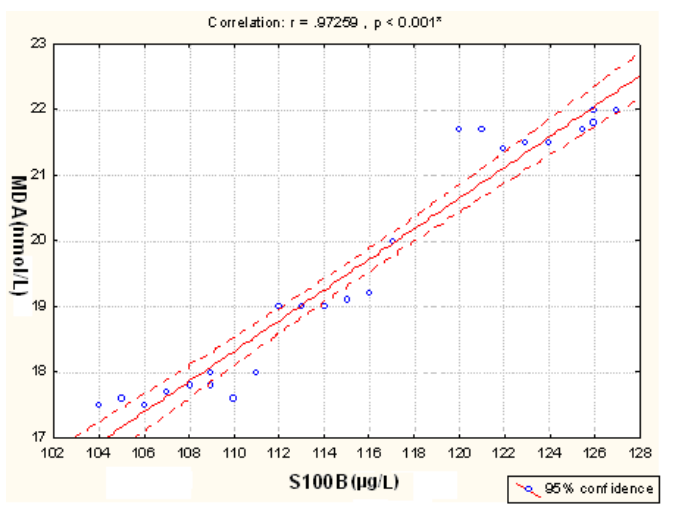

Figure (4) Correlation between levels of $S-100 B$ and MDA in the stroke group.

Figure 4 shows a significantly positive correlation between levels of NSE and MDA $(r=0.97259, \mathrm{P}<0.001)$.

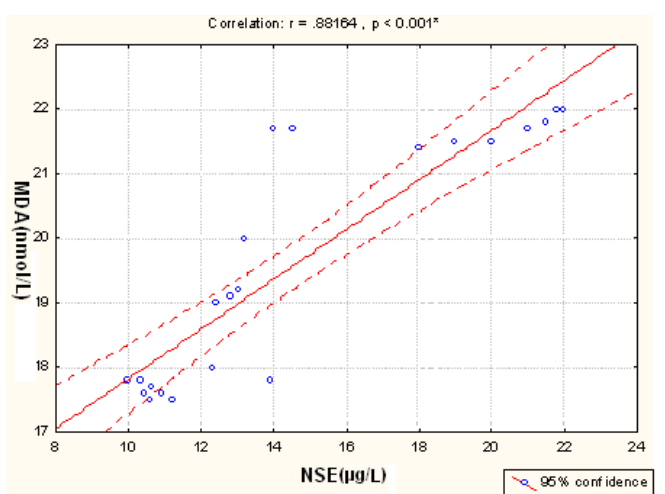

Figure (5) Correlation between levels of NSE and MDA in the stroke group.

Figure 5 shows a significantly positive correlation between levels of NSE and MDA $(r=0.88164, \mathrm{P}<0.001)$.

However, there was no statistically significant correlation between either of S-100B and NSE on one hand and duration of the disease or the glycemic control (HbA1c) $(\mathrm{P}>0.05)$ in all patients.

\section{DISCUSSION}

In the present study, we investigated the association between the extent of brain injury, and serum S-100B and NSE levels in cerebral injury caused by cerebral ischemic stroke in diabetic patients.

The mean level of serum S-100B in diabetic patients with cerebrovascular stroke was significantly higher than that in uncomplicated diabetic patients and the control subjects.

Serum S-100B level in diabetic stroke patients showed significant 
positive correlation to the infarct size as assessed by the CT brain. Similarly, serum levels of NSE was correlated positively with infarct size. In diabetic patients presenting with stroke symptoms and signs, with initially negative CT brain for cerebral infarction, we correlated the serum level of S-100B and NSE with the infarct size (not presented data)detected in the follow up study of CT brain (after 3 weeks). We observed that patients with brain infarcts larger than $5 \mathrm{~cm}^{3}$ showed significantly increased serum levels of S-100B, compared to those with lesion volumes below $5 \mathrm{~cm}^{3}$. These findings agreed with Herrmann et al. ${ }^{(38)}$, who explained this by postischemic release of this biochemical marker. The S- $100 \mathrm{~B}$ protein is released by injured astrocytes. It can be detected in the peripheral circulation after passage through a disintegrated $\mathrm{BBB}^{(8 \& 39)}$.

The statistically significant higher levels of both S-100B and NSE in diabetic patients with stroke, compared to both control and uncomplicated diabetic patients could be explained by the profound disturbance in the BBB in such patients. This allowed the passage of large amounts of S-100B and NSE into the blood. Brain injury causes a selective leakage of S-100B into the cerebrospinal fluid and blood ${ }^{(\mathbf{1 6})}$, so that serum S-100B levels were found to be good indicators for the assessment of patients with cerebral ischemia $^{(16)}$.

Serum S-100B showed statistically significant lower mean value in uncomplicated type 2 diabetic patients compared to its mean value in the control group. However, there was no statistically significant difference between the mean value of NSE in type 2 uncomplicated diabetic group and the control group. In the present study, there were no statistically significant correlation between the HbA1c levels and serum S-100B levels in all patient groups. These observations suggest that the changes in serum S-100B concentrations are not dependent on short-term glycemic control. Results of the present study also showed that serum S-100B levels did not correlate to the duration of diabetes. The latter observation is confounded by the uncertainties of defining the onset of diabetes in subjects with type 2 diabetes.

Similar results were obtained by Hovsepyan et al. ${ }^{(\mathbf{4 0 )}}$. However, Baydas et al. ${ }^{(41)}$, reported that $\mathrm{S}-100 \mathrm{~B}$ protein expression in different areas of brain tissues significantly increased in diabetic rats compared to control rats. Similarly, NSE levels were also significantly elevated in hyperglycemic rats. In addition, there was a significant increase in lipid peroxidation as indicated by elevated MDA in the diabetic rat brain compared to control rat brains.

The controversy with our results as regards levels of S-100B and NSE could be explained by the fact that we studied their levels in serum, not in brain tissue. The disturbance in BBB could not be enough to allow passage of the excess levels of these two parameters into the serum. Dai et al. ${ }^{(42)}$, conducted a study which concluded that the $\mathrm{BBB}$ in diabetic patients is well maintained. Therefore, elevation of both parameters is confined to the brain and does not 
escape to the general circulation owing to competence of BBB. However, MDA which reflects lipid peroxidation LPO showed statistically significant higher mean values in diabetics with stroke compared to its mean values in uncomplicated diabetics and control groups. This could be explained by the fact that MDA is produced as a result of oxidative stress in multiple tissues; not only the CNS.

The decrease in serum S-100B levels observed in type 2 uncomplicated diabetics group compared to the corresponding mean value in the control group is not readily explainable. In previous studies, S-100B expressing tissues (brain, white fat and testes) of streptozotocin-induced diabetic rats, and S-100B protein levels were increased approximately by twofold, while steady state S-100B messenger RNA (mRNA) levels were decreased ${ }^{(43)}$. These observations were in disagreement to previously published studies in diabetic rats that reported decreased S-100B protein content in adipose tissue ${ }^{(44)}$. This was explained by other researchers who suggested that the release of S-100B protein from adipose tissue is significantly inhibited by insulin. Thus, in the present work, it was possible that insulin-treated type 2 diabetic subjects might have reduced release of this protein into the plasma. However, this speculation is confounded by a lack of correlation between measures of glycemic control (HbA1c) and serum S-100B concentrations. It is noteworthy that type 2 diabetes is also associated with reduced cellular content of calmodulin, another intracellular calcium binding protein ${ }^{(45)}$.

The diabetes related changes in serum levels of S-100B in humans have been previously studied. Serum levels of S-100B and NSE in diabetic subjects with history of severe hypoglycemia were not different from those without such history ${ }^{(46)}$. In that study, there was no comparison made with healthy controls. However, in two of the three subjects who died following hypoglycemia, serum concentrations of S-100B and NSE were markedly elevated. The authors concluded that the measurement of serum concentrations of S-100B and NSE might have a prognostic role in evaluating clinical outcome following severe hypoglycemia ${ }^{(46)}$. In one case of diabetic ketoacidosis in the same study, serum S-100B concentration rose coinciding with the onset of cerebral edema ${ }^{(47)}$.

Nonenzymatic glycoxidation in diabetics, which ultimately leads to the formation of advanced glycation end products (AGEs), occurs when free amino groups are exposed to aldoses, such as high levels of glucose, and under conditions of oxidant stress, both of which occur in diabetes ${ }^{(48)}$. The receptor for AGE (RAGE) is a member of the immunoglobulin superfamily of cellsurface molecules. As the biology of RAGE has evolved, several common themes have emerged. First, the multiligand character of the receptor is quite remarkable. Ligands of the receptor include AGEs, crossed-sheet fibrils characteristic of amyloid, amphoterin, and S-100/calgranulins. Even within a particular ligand family, RAGE recognizes more than one 
species. For example, the S100 /calgranulins comprise a family of more than 15 polypeptides. RAGE interacts with S-100A species and S100B (two rather divergent family members), raising the likely possibility that this receptor may well interact with multiple, and may be even all, S-100/calgranulins. A second salient feature of RAGE biology is the presence of more than one ligand in tissues for prolonged times. For example, in diabetic tissues, both AGEs and S-100/calgranulins are present at increased levels in many cases $^{(48)}$. Another unusual feature of the receptor is its apparent colocalization to sites where its ligands tend to accumulate ${ }^{(48)}$. Thus, where AGEs and S-100/calgranulins accumulate at sites of vascular lesions, higher levels of RAGE are also identified in cellular elements. This observation raises the possibility that the presence of ligands upregulates expression of the receptor, potentially resulting in exaggerated RAGEmediated cellular activation. This has been demonstrated directly with S$100 \mathrm{~B}$ and appears to be true with AGEs, amphoterin, and amyloids ${ }^{(4)}$.

The broad consequences of RAGE-ligand interaction for cellular properties are emphasized by the spectrum of signaling mechanisms, which the receptor triggers following ligand occupancy. One such consequence of AGE-RAGE interaction is the generation of reactive oxygen species (ROS) such as $\mathrm{H}_{2} \mathrm{O}_{2}$ and $\mathrm{O}_{2}{ }^{-(49 \& 50)}$. The present study confirms the significant increase in MDA (a marker of lipid peroxidation occurring in conditions of oxidative stress) in diabetics compared to control subjects. The increase was still more significant in patients complicated with stroke. The increased neuronal damage secondary to oxidative stress in diabetes mellitus explains the increase in serum S-100B and NSE. However, in the current study this was clear in patients with stroke. This is due to leakage of these proteins into the blood due to damaged $\mathrm{BBB}$ as previously explained.

\section{Conclusion:}

From the current study we could conclude that, S-100B and NSE correlated with the neurological examinations, as well as the infarct size as assessed by brain CT. So S100B and NSE measurements immediately after admission might help to reduce serial follow up CT scans of the brain of ischemic stroke in diabetic patients. Future studies are recommend, to follow the $\mathrm{S}-100 \mathrm{~B}$ and NSE serum levels, after thrombolytic therapy. Elevation of MDA in diabetic patients, which was significantly higher in diabetic patients complicated with stroke compared to uncomplicated diabetics, might direct future studies using antioxidants.

\section{REFERENCES}

1. Aragno $\mathbf{M}$, Mastrocola $R$, Medana C, Restivo F, Catalano MG, Pons N, Danni O, Boccuzzi G. Up-regulation of advanced glycated products receptors in the brain of diabetic rats is prevented by antioxidant treatment. Endocrinolog. 2005; 146:55615567.

2. Haidara MA, Yassin HZ, Rateb M, Ammar H, Zorkani MA. 
Role of oxidative stress in development of cardiovascular complications in diabetes mellitus. Curr. Vasc. Pharmacol. 2006; 4(3): 215-227.

3. Hatfield RH, McKernan RM. CSF neuron-specific enolase as a quantitative marker of neuronal damage in a rat stroke model. Brain Res. 1992; 577: 249-252 .

4. Hawkins CL, Davies MJ. Generation and propagation of radical reactions on proteins. Biochim. Biophys. Acta. 2001; 1504: 196-219.

5. Beaudeux J, Dequen $L$, Foglietti M. Pathophysiologic aspects of S-100beta protein: a new biological marker of brain pathology. Ann. Biol. Clin. (Paris). 1999 ;57:261-272

6. Heizmann CW, Fritz G, Schafer BW. S-100 proteins: structure, functions and pathology. Front. Biosci. 2002; 7: 1356- 1367 .

7. Korfias S, Stranjalis G, Papadimitriou A, Psachoulia C, Daskalakis G, Antsaklis A, Sakas DE. Serum S-100B protein as a biochemical marker of brain injury: a review of current concepts. Curr. Med. Chem.2006;13(30):3719- 3

8. Bertsch $\mathbf{T}$, Casarin $\mathbf{W}$, Kretschmar M, Zimmer W, Walter S, Sommer C , Muehlhauser F, Ragoschke A, Kuehl S, Schmidt R, Eden BP, Nassabi C, Nichterlein T, Fassbender K. Protein S-100B: a serum marker for ischemic and infectious injury of cerebral tissue. Clin. Chem. Lab. Med. $2001 ; 39: 319-323$
9. Wong $\mathrm{CH}$, Rooney SJ, Bonser RS. S-100ß release in hypothermic circulatory arrest and coronary artery surgery. Ann. Thorac. Surg. 1999; 67:19111914.

10. Ingebrigtsen $T$, Waterloo $K$, Jacobsen EA, Langbakk B, Romner B. Traumatic brain damage in minor head injury: relation of serum S-100 protein measurements to magnetic resonance imaging and neurobehavioural outcome. Neurosurgery. 1999;45:468-475.

11. Buttner $T$, Lack $B$, Jager $M$, Wunsche W, Kuhn W, Muller T, Przuntek H, Postert T. Serum levels of neuron-specific enolase and S-100 protein after single tonic-clonic seizures. J. Neurol. 1999; 246: 459-461

12. Wunderlich MT, Ebert AD, Kratz T, Goertler M, Jost S, Herrmann M. Early neurobehavioural outcome after stroke is related to release of neurobiochemical markers of brain damage. Stroke. 1999;30:1190-1195

13. Sheng JG, Mrak RE, Rovnaghi C, Kozlowska E, Van Eldik LJ, Griffin WS. Human brain S100B and S-100B mRNA expression increases with age: pathogenic implications for Alzheimer's disease. Neurobiol Aging 1996;17:359-363.

14. Lara DR, Gama CS, Belmontede-Abreu P, Portela LVC, Gonçalves CA, Fonseca $M$, Hauck S, Souza DO. Increased serum S-100B protein in schizophrenia: a study in 
medication-free patients. J. Psychiatr. Res. 2001;35:11-14.

15. Walz R, Portela LVC, Tort ABL, Neto EC, Fernandes LN, Gonçalves CA. Serum S-100B levels in patients with HTLV-I associated myelopathy/tropical spastic paraparesis. Neurology. 2000;54:2021-2022

16. Portela LV, Brenol JC, Walz R, Bianchin M, Tort AB, Canabarro UP, Beheregaray S, Marasca JA, Xavier RM, Neto EC, Goncalves CA, Souza DO. Serum S-100B levels in patients with lupus erythematosus: preliminary observation. Clin. Diagn. Lab. Immunol. 2002; 9:164-166.

17. Fletcher L, Rider CC, Taylor CB. Enolase isoenzymes. III. Chromatographic and immunological characteristics of rat brain enolase. Biochimica et Biophysica Acta. 1976; 452: 245252.

18. Marangos PJ, Campbell IC, Schmechel DE, Murphy DL, Goodwin FK. Blood platelets contain a neuron-specific enolase subunit. Journal of Neurochemistry. 1980; 34: 12541258.

19. Day IN, Thompson RJ. Levels of immunoreactive aldolase $\mathrm{C}$, creatine kinase-BB, neuronal and non-neuronal enolase, and 14-3-3 protein in circulating human blood cells. Clinica. Chimica. Acta. 1984; 136: 219-228.

20. Anastasiades KD, Mullins RE, Conn RB. Neuron-specific enolase. Assessment by ELISA in patients with small cell carcinoma of the lung. American Journal of
Clinical Pathology 1987;87: 245249.

21. Hay E, Royds JA, Davies-Jones GA, Lewtas NA, Timperley WR, Taylor CB. Cerebrospinal fluid enolase in stroke. Journal of Neurology, Neurosurgery and Psychiatry 1984;47: 724-729.

22. Persson L, Hardemark HG, Gustafsson J, Rundstrom G, Mendel-Hartvig I, Esscher T, Pahlman S. S-100 protein and neuron-specific enolase in cerebrospinal fluid and serum: markers of cell damage in human central nervous system. Stroke 1987;18: 911-918.

23. Roine RO, Somer $H$, Kaste $M$, Viinikka L, Karonen SL. Neurological outcome after outof-hospital cardiac arrest. Prediction by cerebrospinal fluid enzyme analysis. Archives of Neurology 1989; 46: 753-756.

24. Studahl M, Rosengren $L$, Gunther G, Hagberg L. Difference in pathogenesis between herpes simplex virus type 1 encephalitis and tick-borne encephalitis demonstrated by means of cerebrospinal fluid markers of glial and neuronal destruction. Journal of Neurology 2000; 247: 636-642.

25. Royds JA, Timperley WR, Taylor CB. Levels of enolase and other enzymes in the cerebrospinal fluid as indices of pathological change. Journal of Neurology, Neurosurgery and Psychiatry 1981;44: 1129-1135.

26. Correale J, Rabinowicz AL, Heck CN, Smith TD, Loskota WJ, DeGiorgio CM. Status epilepticus increases CSF levels 
of neuron-specific enolase and alters the blood-brain barrier. Neurology 1998;50: 1388-1391.

27. Misler $U$, Wiesmann $M$, Friedrich C, Kaps M. S-100 protein and neuron-spesific enolase concentrations in blood as indicators of infarction volume and prognosis in acute ischemic stroke. Stroke 1997; 28: 19561960 .

28. American Diabetes Association, Standards of Medical Care in Diabetes. Diabetes Care 2006; 29:S4-S42.

29. Holland MC. Craniocerebral trauma. In" Current surgical diagnosis and treatment". Edited by Way LW and Doherty GM. $11^{\text {th }}$ edition. pp 900-927. Published by Langue medical books. Mc Graw-Hill.2003.

30. Trinder $\mathbf{P}$. Determination of glucose in blood using glucose oxidase with an alternative oxygen acceptor. 1969; Ann Clin Biochem; 6:24-27.

31. Danilova LA and Lopatina NI. Colorimetric method of determining glycosylated hemoglobins. Lab. Delo. 1986; 5: 282- 283.

32. Delmas HG. Biochemical analysis of human and animal serum for monoclonal antibodies using ELISA. Biochemistry 1986;14: 214-231.

33. Matthews DR, Hosker JP, Rudenski AS, Naylor BA, Treacher DF, and Turner RC. Homeostasis model assessment: insulin resistance and beta-cell function from fasting plasma glucose and insulin concentrations in man.

Diabetologia 1985; 28:412 -419.

34. Michetti F and Gazzolo D. S100B protein in biological fluids: A tool for perinatal medicine. Clin. Chem. 2002; 48: 20972104.

35. Dahlen U, Karlsson B, Nilsson O, Uhl W. Development of an Enzyme Immunoassay. NSEEnzyme Test for determination of Neuron -specific enolase. 1995; XXIII International Society for Oncodevelopmental Biology and Medicine, Montreal, Quebec.

36. Satoh K. Serum lipid peroxide in cerebrospinal disorders determined by a new calorimetric method. Clin. Chem. Acta. 1978; 37-43.

37. Saunders D and Trapp G. Basic and clinical Biostatistics. 2001; $3^{\text {rd }}$ edition, Connecticut, Appleton and Lang.

38. Herrmann $M$, Vos $P$, Wunderlich MT, de Bruijn CH, Lamers KJ. Release of glial tissue-specific proteins after acute stroke: A comparative analysis of serum concentrations of protein S-100B and glial fibrillary acidic protein. Stroke. 2000; 31:26702677 .

39. Mussack T, Hauser C, Klauss V, Tato F, Rieger J, Ruppert V, Jochum M, Hoffmann U. Serum S-100B protein levels during and after successful carotid artery stenting or carotid endarterectomy. J. Endovasc. Ther. 2006 ;13(1):39-46

40. Hovsepyan MR, Haas MJ, Boyajyan AS, Guevorkyan AA, Mamikonyan AA, Myers SE, Mooradian AD. Astrocytic and 
neuronal markers in the sera of subjects with diabetes mellitus. Neuroscience Letters 2004; 369: 224-227.

41. Baydas G, Sonkaya E,Tuzcu M,Yasar A, Donder E. Novel role for gabapentin in neuroprotection of central nervous system in streptozotocine-induced diabetic rats. Acta. Pharmacologica. Sin. $2005 ; 26: 417-422$

42. Dai J, Vrensen GF, Schlingemann RO. Blood-brain barrier integrity is unaltered in human brain cortex with diabetes mellitus. Brain Res. 2002; 954: 311- 316 .

43. Zimmer DB, Chessher GL, Wilson GL, Zimmer WE. S100A1 and S-100B expression and target proteins in type 1 diabetes. Endocrinology 1997; 138: 5176-5183

44. Suzuki F, Kato K. Inhibition of adipose S-100 protein release by insulin. Biochim. Biophys. Acta. 1985; 30: 311-316.

45. Morley JE, Levine AS, Beyer HS, Mooradian AD, Kaiser FE, Brown DM. The effects of aging and diabetes mellitus on human red and white cell calmodulin levels. Diabetes 1984; 33: 77-80.

46. Strachan MW, Abraha HD, Sherwood RA, Lammie GA, Deary IJ, Ewing FM, Perros P,
Frier BM. Evaluation of serum markers of neuronal damage following severe hypoglycemia in adults with insulin-treated diabetes mellitus. Diabet. Metab. Res. Rev. 1999; 15: 5-12.

47. McIntyre EA, Abraha HD, Perros P, Sherwood RA. Serum $\mathrm{S}-100$ beta protein is a potential biochemical marker for cerebral edema complicating severe diabetic ketoacidosis. Diabet. Med. 2000; 17: 807-809.

48. Wendt T, Bucciarelli L, Qu W, Lu Y, Yan SF, Stern DM, Schmidt AM. Receptor for advanced glycation end products (RAGE) and vascular inflammation: insights into the pathogenesis of macrovascular complications in diabetes. Curr. Atheroscler. Rep. 2002;4:228 237.

49. Chappey O, Dosquet C, Wautier MP, Wautier JL. Advanced glycation end products, oxidant stress and vascular lesions. Eur. J. Clin. Invest. 1997; $27: 97-108$.

50. Wautier, M-P, Chappey O, Corda S, Stern DM, Schmidt AM, Wautier JL. Activation of NADPH oxidase by AGE links oxidant stress to altered gene expression via RAGE. Am. J. Physiol. 2001; 280 :E685 -E694 


\section{القيمة التشخيصية لبروتين "إس . . اب" و انزيم الاينوليز الخاص بالأعصاب

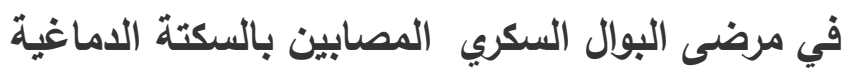

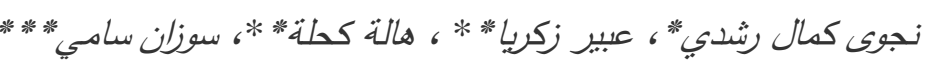

من أقسام * الكيمياء الحيوية الطبية ، **الأمراض الباطنة ، و *** *الأشعة التشخيصية كلية الطب - جامعة القاهرة

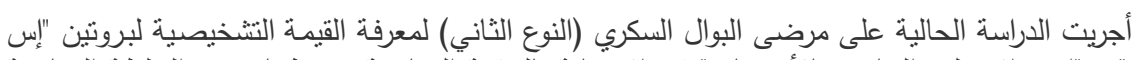

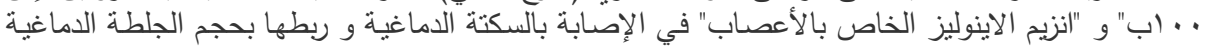

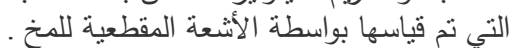
وقد تم تقسيم مجموعات البحث باست إلى :

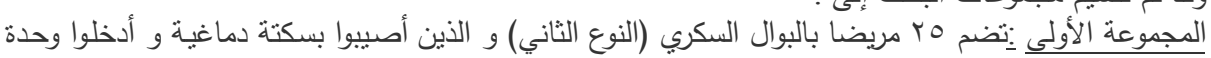

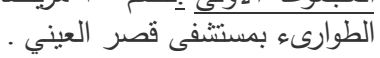

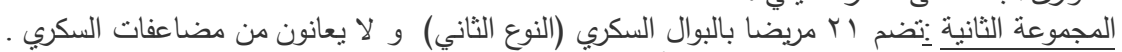

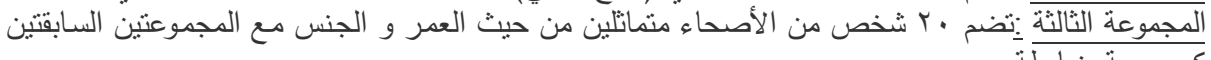
و قد تم قياس المالونديالدهايد كيميائيا (كمؤشر لأكسدة الدهون) و كذللك قياس مستويات "إس . . . اب" و "انزيم

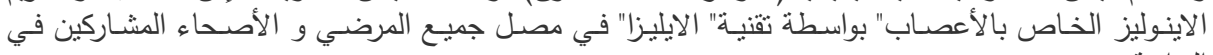

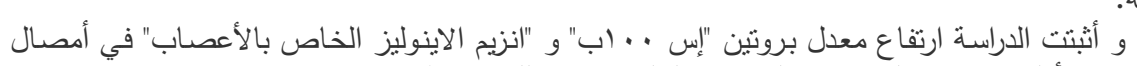

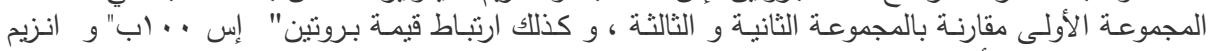

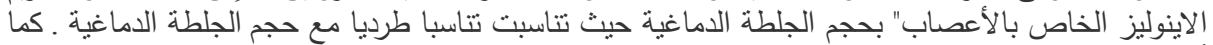

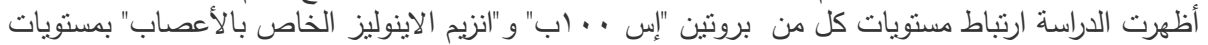

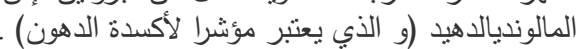

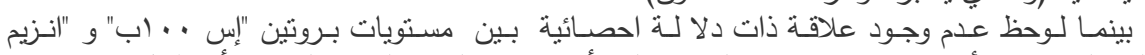

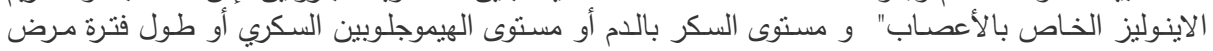

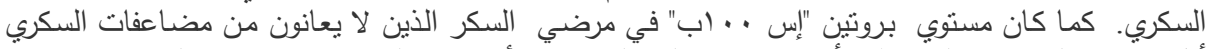

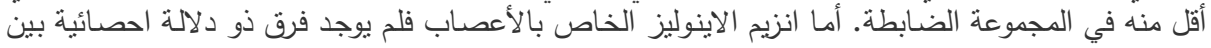

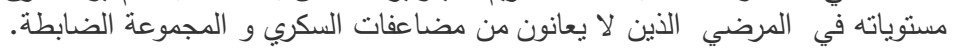

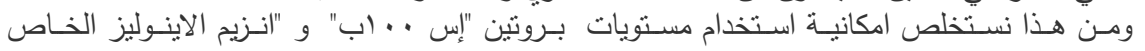

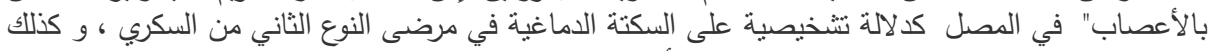

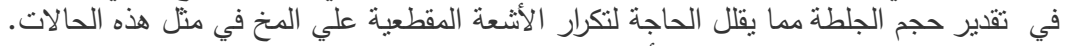

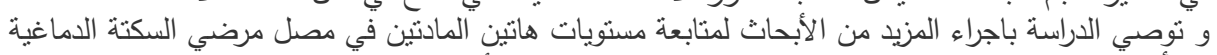

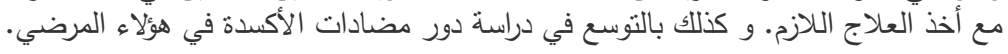

